\title{
A Descriptive Study of the Schooling and Higher Education Reforms in Response to the Refugees' Influx into Greece
}

\author{
Ourania Tzoraki \\ Department of Marine Sciences, University of the Aegean, Lesbos 811 00, Greece; rania.tzoraki@aegean.gr; \\ Tel.: +30-22510-36840
}

Received: 4 November 2018; Accepted: 20 February 2019; Published: 26 February 2019

\begin{abstract}
Since 2015, a large number of migrants (refugees and asylum seekers) from the Middle East, Asia, and Africa have arrived in Greece and continued their onward journey to western European countries where they settled. As various European Union (EU) countries have later blocked the flow of migrants from Greece to their final destination, thousands of them have been trapped in Greece, confined in overcrowded, temporary camps (known as "hot spots") and awaiting the processing of their asylum application. The current article examines the response of the Greek educational institutes (primary, secondary and tertiary levels) to the recent migrant influx, with ultimate goals to integrate, educate, and assist them. The number of refugees and asylum seekers living in Greece is estimated to be 58,000 (2018 data) with 22,500 children among them. Their schooling inclusion follows the plan 111, "Refugee Education Host Structures (REHSs)", as initiated by the Greek Ministry of Education in 2017. Students' leakage range is still high (10-40\% at elementary school and $45-56 \%$ at high School). The disruption in their life results in the lack of regular attendance. Greek universities responded to the challenge of the refugee influx, especially the University of the Aegean (UAeg), which is located on the eastern Mediterranean migration route. The UAeg's response plan focuses on four areas: (a) to provide education to refugees; (b) to conduct research on the refugee phenomenon and migration processes; (c) to increase local citizens' awareness and improve social inclusion toward the migrants; and (d) to develop technologies to improve daily life in the refugee camps. These actions are significant toward the social inclusion and cohesion of refugees and the further improvement of their daily life.
\end{abstract}

Keywords: refugees; asylum seekers; schools; universities; Lesvos

\section{Introduction}

The Syrian Civil war forced millions of people to seek asylum in neighboring and European countries. Thousands of them headed for the West and North European countries, especially Germany and Sweden, expecting to find there valuable support, protection, and a better future (Afouxenidis et al. 2017). However, in 2015, a massive movement of refugees (initially mainly Syrian) was observed from the Eastern Mediterranean route along the Western Balkan route (Figure 1) (Streitwieser et al. 2017).

The Eastern Mediterranean route includes the Greek islands (Figure 1) of the Eastern Aegean due to their proximity to Turkey (Mavrommatis 2018). According to the United Nations High Commissioner for Refugees (UNHCR) official data, 817,175 people passed through the maritime sea route from Turkey to Greece during 2015-2016, while 410 drowned and 176 were listed as missing. However, unofficially, it is estimated that the number of refugees crossing the country exceeded one million. These people traveled from the Aegean islands to the port of Piraeus and then reached the Greek-Former Yugoslavian 
Republic of Macedonia border. Subsequently, many European Union (EU) countries were forced to close their borders and blocked the transit routes for the migrants. As a result, long waiting periods have ensued for those who remained in South European countries such as Greece and Italy. In particular, more than 60,000 refugees and asylum seekers were forced to remain in Greece awaiting the processing of visa and asylum applications. Refugees' arrival numbers from 2016 to the summer of 2018 are showing a declining trend according to the Eurostat dataset. It is worth mentioning that the numbers are changing on a daily basis (Figure 2), for example, whereas on 23 May 2017 the number of refugees in Lesvos was 3472, it reached 9678 on 16 July 2018 (https:/ / www.emprosnet.gr/prosfyges).

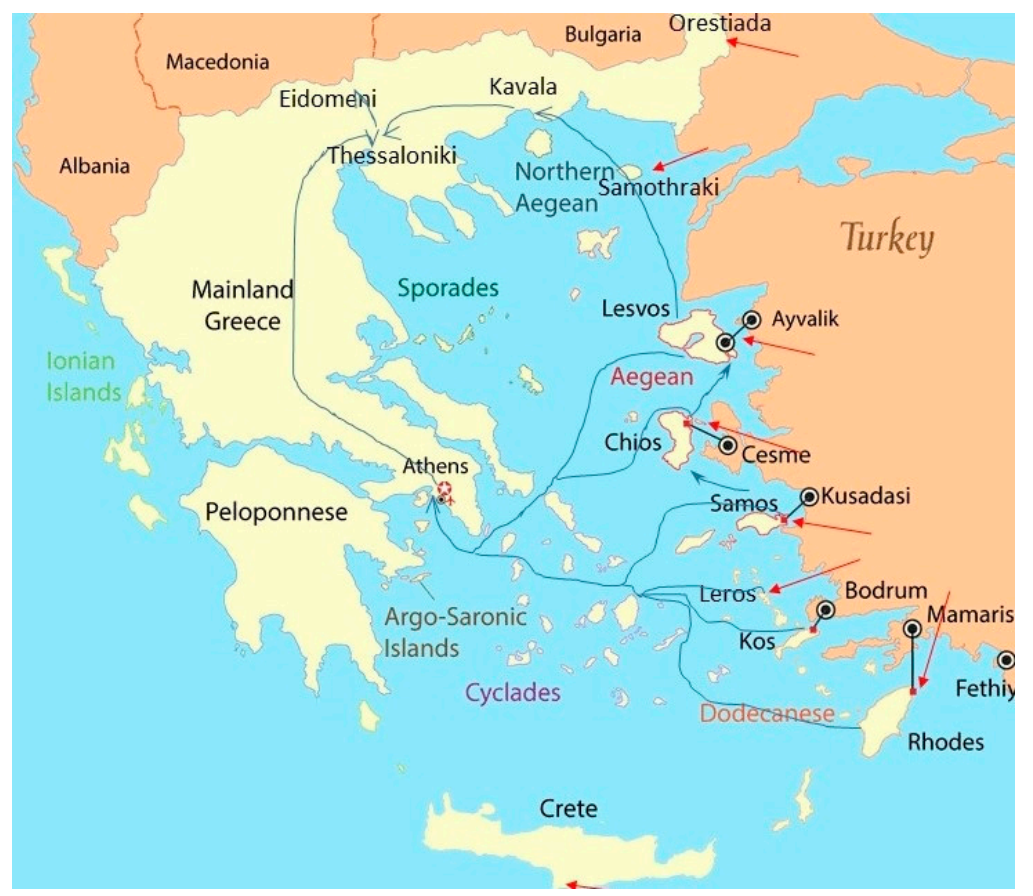

Figure 1. Migrant routes, modified from Source: United Nations High Commissioner for Refugees (UNHCR 2017).

In 2015, the Greek government was unprepared to face the refugee influx in terms of both procedures and infrastructures. However, services were soon organized and coordinated by the United Nations High Commissioner for Refugees (UNHCR) and/or public authorities in order to cover basic needs such as provision of food, health, settlement in camps and private houses, and assistance with asylum applications (Afouxenidis et al. 2017). Various refugee camps were set up on mainland Greece and on some Aegean Sea islands. One such camp is the Moria camp (capacity of $\sim 5000$ people), as well as the Kara-Tepe camp (capacity 1100 people) on Lesvos Island.

The camp design and development followed a traditional approach of centralized decision-making (Jahre et al. 2018), with some traces of new approaches such as the trials of environmental impact assessment (waste control via recycling, gardening, etc.). The chronicity of crisis is visible in the various projects in the camps (related to education, social integration, entertainment, culture) as its structures become more permanent rather than temporary and where relationships and future plans start to follow long-term concepts. For instance, the mainstreaming of children living in camps into the Greek public schools is an important integration process that has become normalized (Zsófia 2018). Specific structures are active for the children to leave the camps and join the normality of the public schools. However, complications arise in that process such as the availability and preparedness of the teachers, the restricted available positions in the public classes, the children and the parental response, and the response of the wider society. The refugee children's behavior inside the classes is not often characterized by discipline, assumed as the cornerstone of education, or by self-motivation; this is 
attributed to the destruction of their daily life. It is worth mentioning that in Lebanon and Jordan, despite the huge efforts to engage Syrian youths in education, only $7 \%$ of the youth and adolescents are active in the program implementation (Visconti and Gal 2018).

The continuing in-flow of hundreds of refugees into Greece and the frozen transience in the Greek territories are pressing issues for adapting educational structures and reforms of the conventional educational system. This article critically examines the adaptation of the Greek schooling system and the planning of the higher education sector of Greece to accept and integrate refugees through the case study of the University of the Aegean (UAeg). The UAeg is the only institute of tertiary education active in the Aegean islands. It operates 18 academic departments and 42 Master's Degree programs on six islands. In four of them, namely, Lesvos, Chios, Samos, and Rhodes, thousands of refugees are "trapped" and live in the camps. While the number of refugees entering Lesvos each week remains low ( 300) since 2017 (Figure 2) (UNHCR 2018b), there has been a higher demand from migrants to enter school and/or university in order to improve their professional skills or join the labor market.

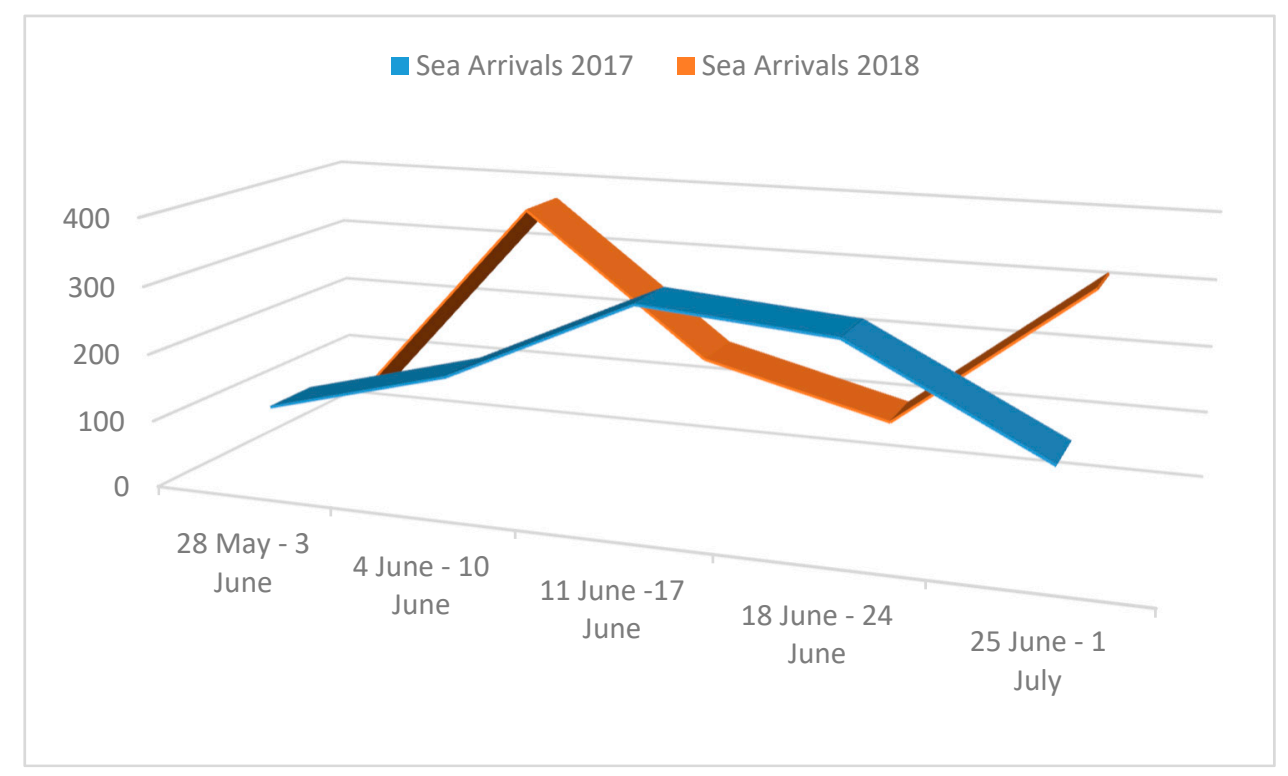

Figure 2. Comparison of sea arrivals on Lesvos island between 2017 and 2018 (UNHCR 2018b).

\section{Methodology}

An informative framework which was used to help, explain, and analyze the response of universities to the refugee crisis is the Disaster Resilience Universities (DRU) approach proposed by Kapucu and Khosa (2013). Resilience is the concept to improve the capacity of the systems, the physical structures, and the community to react effectively and overcome natural disasters (i.e., earthquakes, floods). A DRU is essentially prepared only when specific operation schemes are developed based on a) an all-hazards plan, b) regular training and exercises to mitigate and respond to various hazards, and c) a strongly developed community partnership (Kapucu and Khosa 2013). In Greece, the urgency to help the incoming refugees has created additional pressure on the local community and the university members to provide supporting material, services, mechanisms, and coordination that leaders did not expect and were not prepared for. Two distinct phases were differentiated: the first phase of the "refugee in-flow boom" of 2015 with the higher need to rescue people and provide basic emergency items and the second current phase of the "in-flow chronicity" of a well-organized welfare system with available shelters, lifeguards, coordination, transportation, nutrition, and health and educational units. However, the majority of the effort has been carried out by the universities in "risk identification", in "risk mitigation" and in "improving the capacity and the capability of the institutes" to adapt to the refugee needs. 
Due to the strong interconnection between primary and secondary education and tertiary education, this study examined the Greek system's response to integrating the refugees into the schooling process. The universities' internationalization is assumed as a positive factor for the effective integration of refugees. The internationalization rate of Greek universities is studied based on the attractive factors that make them competitive in the global tertiary sector arena. Then, the case study of the University of the Aegean was selected due to its proximity to the entry points and the major refugee camps of the country to study its response to the refugee crisis.

The current research was based on reports of the period 2015-2018 published in mass media by public services (municipality, prefecture, Greek government) (the majority in the Greek language), non-governmental organizations (NGOs) (i.e., United Nations International Children's Emergency Fund (UNICEF), UNHCR and research institutes. A significant number of scientific articles have been available in scientific journals since the beginning of the refugee in-flows and were used for the current study. In addition, thorough research was conducted to find out and register the response of the University of the Aegean in the refugee matters based mostly on the author's personal communication with the university members. Finally, visits made by the author to the refugee camps and NGO facilities on Lesvos and her involvement in the bi-monthly Lesvos Inter-Agency Consultation Forum enabled many possibilities of data collection.

\section{Contextual Factors}

Greece is a country that traditionally has a relatively homogeneous population and relatively limited experience with immigrant integration processes. Within a population of 10,816,286 (2011 census data, Hellenic Statistical Authority), and as reported in a study by the National Center for Social Research, the number of documented data immigrants from non-EU countries is 621,178 (5.7\% of the total population), which is considered very low compared to Germany that has about $12 \%$ (the highest among the EU member states). The number of documented migrants shows an increasing trend over the last years (from 405,306 in 2013 up to 557,476 in 2016 after the first year of the refugee crisis).

The documented immigrants originate from 12 countries, mainly from the Third World, which are the largest groups of foreigners in Greece, based on the Ministry of the Interior's updated statistics (19 April 2016). The majority of legally residing foreigners come from Albania $(387,023)$, Ukraine (19,595), Georgia (18,334), Pakistan (16,578), India (14,357), Egypt (12,084), Philippines (10,468), Bangladesh (6301), Syria (5799), China (4840), and Serbia (2968).

Examining the schooling of immigrant children, an analysis of the 2006-2007 school year statistics data showed that the number of foreign and repatriated students in elementary and secondary education was 130,362 (10\%) of the total of 1,301,595 students (IEF 2007). Only 13 inter-cultural elementary schools and 13 high schools operate in Greece that can serve a limited number of students (Database 2008).

With regard to Greek higher education, the number of international students $(29,012$ non-citizen students) (OECD.Stat 2019) entering Greek universities is relatively small in comparison to the overall number of domestic students (a total of 306,454 students in the tertiary education for the academic year 2014-2015, Table 1) (ELSTAT 2018). During the period 1974-1996, the ratio of international students in the student body was $10 \%$, slightly less than the $12.3 \%$ of German universities. In the relative comparative scale (average number for the period 1968-1998), Cypriots (60\%) accounted for the largest number of international students in Greece, followed by Asians (20\%), predominantly from the Middle East and Turkey, and then African (7\%) and European students (7\%), while a significantly smaller number of students came from the American continent (4\%) and Oceania (1\%).

The Ministry of Education sets the percentage of foreign students that can enter Greek State universities. This stands at $1 \%$ for the first scientific field (Humanitarian, Social, and Law sciences) and $0.5 \%$ for the remaining fields, resulting in 29,012 students in 2014-2015, for example. There are also some English-speaking independent higher education colleges in Greece, and in 2009 it was estimated 
that 2500-3000 foreign students, mainly from the Balkans and China, were studying in the foreign language sections.

Table 1. Number of pupils and students in all Greek education levels (Source: The Hellenic Statistical Authority (ELSTAT)) through the quarterly publication Greece in figures of 2018.

\begin{tabular}{cc}
\hline Education Level & Academic Year 2014-2015 \\
\hline Primary sector: Kindergartens & 162,781 \\
\hline Primary sector: Elementary schools & 640,001 \\
\hline Lower Secondary schools & 315,920 \\
\hline Higher Secondary schools & 239,273 \\
\hline Tertiary education (Technical sector) & 99,389 \\
\hline Tertiary education (Universities) & 174,039 \\
\hline Master's Students & 9231 \\
\hline PhD Students & 23,795 \\
\hline Total & $1,664,429$ \\
\hline
\end{tabular}

In recent years, the higher education sector has positively responded to the pressing need for international students and the attraction of EU funds. Greek academic institutions have undertaken actions to internationalize their studies in Greece and enhance the extroversion of higher education. They signed bilateral international agreements with university institutions from EU and non-EU countries to promote cooperation and exchange on research and education. Numerous postgraduate programs exist in the English language, and the International Hellenic University started offering exclusively English programs as of 2005. There is constant participation of Greek universities in international educational events and conferences aiming to increase their recognition and attract students from Third World countries.

\section{Characteristics of Refugees in Greece and Lesvos}

The number of refugees and asylum seekers in Greece is estimated to be 58,100 (data from the UNHRC report of 15 May 2018). The majority of them are residents on mainland Greece $(43,700)$ and the rest on the islands (14,400) (UNHCR 2018c). Information related to the formal procedures followed for asylum seekers and the benefits obtained is provided in the report of the Asylum Information Database (AIDA) (Konstantinou et al. 2018). In total, the number of asylum applications reached 51,091 in 2016, 58,661 in 2017, and 58,100 in 2018 (UNHCR 2018c). The majority of the asylum seekers are of Syrian origin. For instance, in 2016, 26,630 refugees from Syria, 4770 from Iraq, 4420 from Pakistan, 4295 from Afghanistan, and 10,000 from other countries applied to the Greek authorities for asylum. Thousands of them live in numerous camps or the so-called "hot spots" (temporary sites for the initial reception of newly-arrived migrants seeking to move on to other European countries) or in various hotels and rented houses on the Greek Aegean islands and on the mainland.

The number of refugee children across Greece is $22,500(\sim 39 \%$ of the refugee population) and $48 \%$ of them should attend the elementary and high school (compulsory) education level (6-15 years old) and $12 \%$ the preschool level (4-5 years old). Unfortunately, only $45 \%$ of children aged 6-17 attend formal education. Children housed with their families or in shelters for unaccompanied children join the Greek education system at higher rates (56\% of children 5-17 years old) compared to those living in camps (Ministry of Education 2017). On Lesvos, at least 600 refugee children live on the island between the age of 5-18 (February 2017 data from the report of the Greek Ombudsman), who according to the law should be enrolled in the schooling system. The majority of them follow informal education offered by NGOs. In one such informal school, more than 100 are enrolled, divided into four classes of 
different levels and attending courses of English, Greek, Geography, Intercultural education, European literature, History, Mathematics, and Creative employment.

On average, of the 8000 migrants residing on Lesvos, the majority of them are from Syria (30\%), Afghanistan (23\%), and Iraq (19\%) (Figure 3). Women account for 23\% of the migrant population and children for $30 \%$. Some $42 \%$ are men aged $18-39$. The number of migrants living on the island changes on a daily basis; for example, on 16 July 2018 it was 7558 and on 11 December 2018 it had decreased to 5041 (Figure 4). Almost 7\% of the incomers hold a college or a tertiary level education degree and around 1\% hold Master's or PhD degrees (author's research with Moria camp Front Desk, statistics for April and May 2018).

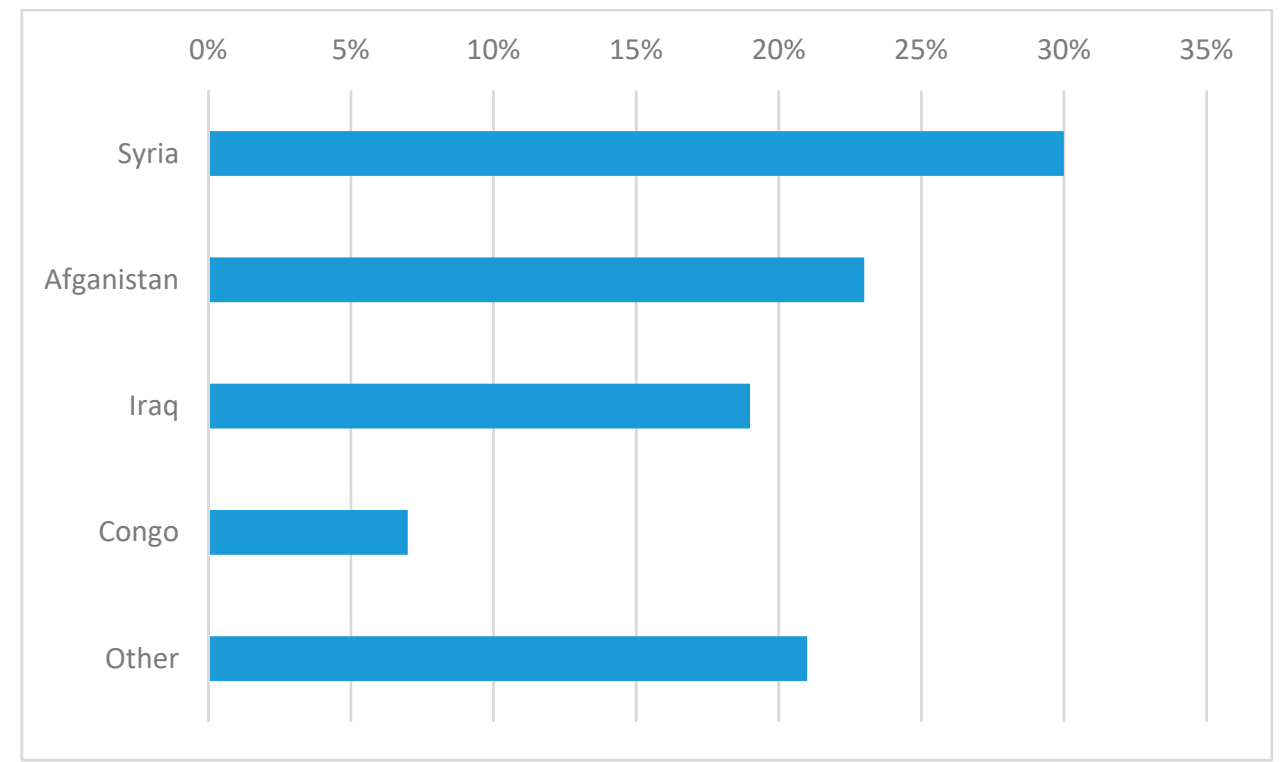

Figure 3. Demographic elements of the refugees arriving on Lesvos island.

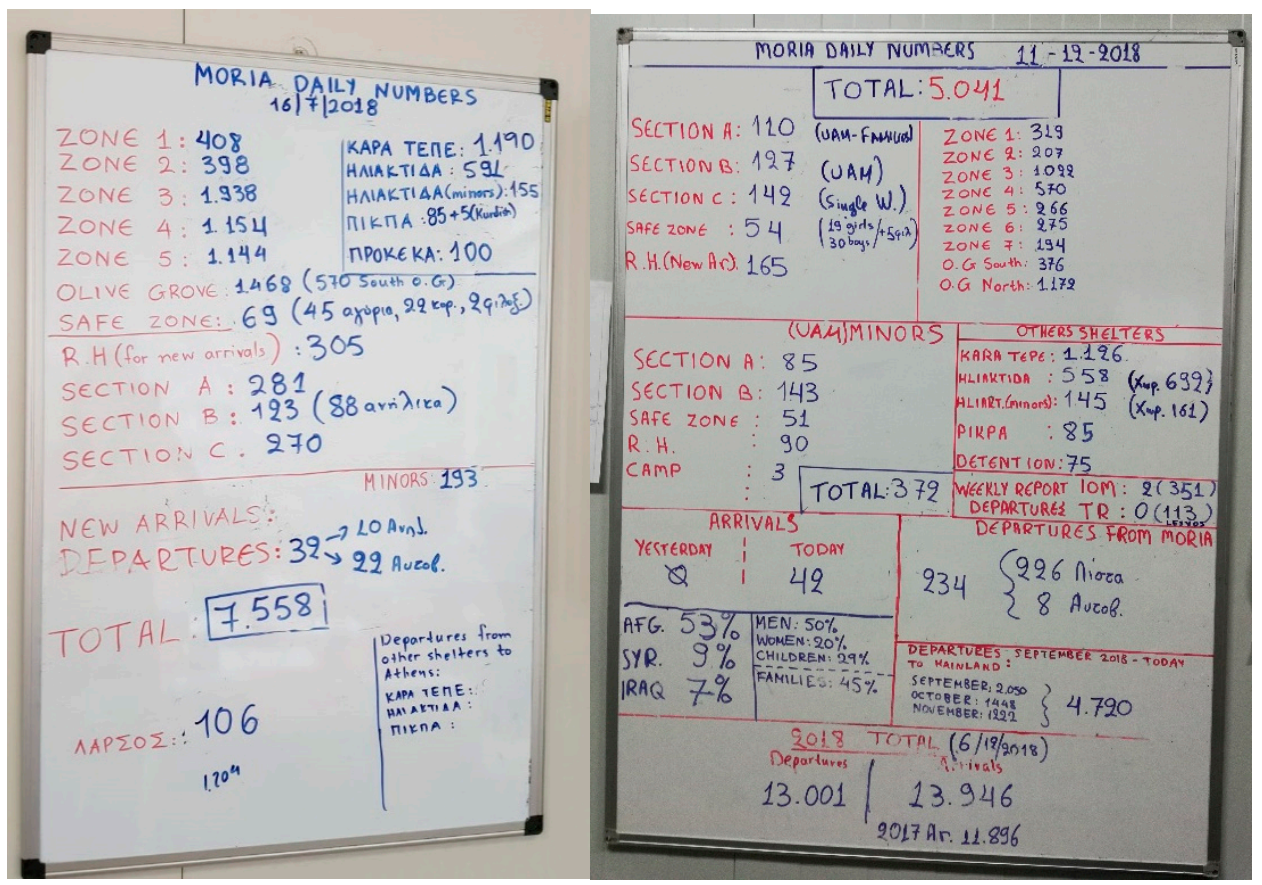

Figure 4. Dashboard at the Moria camp noting daily hosting (16 July (left) and 11 December (right) of 2018). 


\section{The UAeg's Response Plan: Integration into Greek Higher Education}

\subsection{Access to the Education System}

The integration of young refugees into the Greek education system has been a key concern of the Ministry of Education since the beginning of 2016. In March 2016, the ministry set up a Scientific Committee with the objective to develop a plan to integrate migrant children into education in order to facilitate their wider social integration. This plan was implemented by the Management Team, the ministry officials, the Education Coordinators, the teachers assisted by other ministries, and international organizations and institutions (Ministry of Education 2017).

According to this plan, 111 Refugee Education Host Structures (REHSs) with 145 classes were implemented, including more than 2600 pupils (2017 data). A critical role in that procedure was played by the Refugee Education Coordinators (RECs) (62 persons), who were appointed by the Ministry of Education to function as links between REHSs and schools and to coordinate educational actions organized by NGOs and other bodies.

However, in some schools, the pupils attend normal classes with additional educational support (no quantified data available). For the majority of migrant children, their priority is the positive outcome of their application for international protection and secondly the issue of integration into education (Zsófia 2018). During their hosting in camps and other settlements, they have the possibility to follow informal education structures (organized by the NGOs or the Ministry of Education), intended to prepare the children for their full integration into the normal school curriculum (report of the Greek Ombudsman, 2017).

Specific peculiarities had to be addressed by the Ministry, such as the lack of high school certificates or the lack of vaccination for young children. At the same time, however, relatively high rates of school drop-out and inadequate attendance at schools were observed (similar to those observed in other countries), mainly due to the fragile conditions in which refugees live and the educational deficiencies of the REHSs. For example, in Lebanon, Turkey, and Jordan, the proportion of Syrian refugee children drop-out ranges from 48\% to 78\% (Visconti and Gal 2018) and in Greece it was around 10-40\% in elementary school and 45-56\% in high school (Ministry of Education 2017). It is worth mentioning that on Lesvos, of the 159 unaccompanied children under the aegis of the NGO "Iliaktida", 80 attend high school and all 80 were successful in the national exams. This is a good example of fruitful cooperation between the young refugees and various involved partners (teachers, NGOs, public servants) (UNHCR 2018a).

Problems in the functioning of the REHSs and the fulfillment of their educational objectives have created the absence of specific skill requirements in teacher recruitment, their constant rotation, and inadequate training and support. Of particular note is the mass movement of refugees from the camps to several private rooms in urban centers without a timely information flow between the NGOs and the Education Coordinators about the number of people traveling and their destination.

The Ministry of Education has taken the first step toward the social integration of refugees by following a specific plan of implementing, operating, and organizing reception classes and/or REHSs. In some cases, the presence of refugee children in schools initially provoked strong reactions by Greek parents and conflicts (Lazaratou et al. 2017), mainly in schools that receive donations to cover food and other basic needs of the students. All the REHSs eventually functioned, and the experience from the reactions was used to design the next steps more efficiently and effectively.

\subsection{Access to the University of the Aegean}

The migrant influx did not affect the University's operation but created the need for new services and novel curricula.

The University delivered a plan on how it could effectively help and organize its activities. Specifically, it planned (a) to provide education to refugees in order to enhance their linguistic and computer skills; (b) to study the refugee phenomenon and migration processes; (c) to help the local and student community to accept and understand the refugees' plight and smooth any xenophobia 
and other negative attitudes toward them; and (d) to provide technology solutions to improve the refugees' daily lives in the camps.

\subsubsection{Educational Support}

Important actions-especially on the part of the university leaders working in partnership with the community partners (NGOs, United Nations, municipality, etc.) - new curricula and seminars were created in order to support the incomers and make university facilities more adaptable. The main initiatives focused on the admission of the refugees into university, the reintegration of skilled refugee scientists into the academic and research community, the training of refugees (languages, software skills), sessions of training the trainers, and contributions to the education of the refugee children.

The Erasmus+ and the Directorate for Scholarships National Agency of Greece, after responding to a relevant call for expressions of interest, delivered to the University of the Aegean 2000 language learning licenses online to be granted to refugees in the Aegean islands. These language licenses allow refugees to attend online courses for learning a foreign language from the 12 available languages and are part of the Online Linguistic Support (OLS) program of the European Commission. The aim of this action was to strengthen the language skills of refugees and to integrate them into European education and training systems. Online lessons are for people over the age of 12 and access is available from any device with Internet connection. Once the program is completed within 13 months, asylum seekers receive a certificate from the European Commission. In this context, the University of the Aegean in co-operation with the United Nations High Commissioner for Refugees (UNHCR) organized the refugee support process fully and effectively to use this service. Several problems were encountered such as the slow Internet connection in the camps, the need to create e-mail accounts for the refugees to access OLS, and difficulties in accessing e-mail accounts due to lack of previous experience in e-mail use. The majority of the refugees (in a pool of 142) selected the English language (65\%), followed by the Greek (20\%) and German ( $8 \%$ ) languages. The University created manuals on OLS use in Farsi and Arabic and organized training courses for OLS online use in its premises with the help of student volunteers. The UAeg did not receive any financial support to disseminate the OLS service to the migrant community and educate them on its use.

The UAeg is teaching the Greek language to refugees for beginners or at an advanced level and has created a curriculum according to the guidelines of the Greek Language Centre (hereafter CGL) of the Ministry of Education (CGL 2018). At the same time, the UAeg conducts the examinations for the Greek language and provides the certificates.

Science for Refugee Scientists in Aegean Archipelago (SCIREA)-Horizon project: A recent survey of the qualifications of the migrants arriving on Lesvos island showed that almost $7 \%$ of them had a university degree and $1 \%$ of them a Master's or even a PhD degree (SCIREA project findings). The SCIREA project (SCIREA 2018), with the UAeg acting as coordinator, focuses on skilled refugees and helps to integrate them into European academic institutions and to improve their qualifications. Tailor-made seminars and webinars were implemented and scholarships were given to refugee scientists to restart their academic career.

Bridge for Researchers in Danger Going to Europe, Part II (BRiDGE II)—Horizon project: This project aims to enhance the support given to 300 skilled refugee researchers (RRs) in 24 project months, especially early- and late-stage postdoctoral researchers and professors of all ages, who are affiliated with a research institution in the European Research Area or a Research \& Development department of a company and especially those displaced in the following countries: Germany (110 RRs), Sweden (40 RRs), Austria (60 RRs), Switzerland (10 RRs), Serbia (10 RRs), Bulgaria (10 RRs), and Greece (60 RRs). The UAeg is a partner in BRiDGE II by supporting a significant number of RRs to reintegrate into the research and academic community. The case-by-case support places a focus on career development services, training, and academic and industrial mentoring for the RRs. The project further aims to transfer the given knowledge and experience to the EURAXESS network, the largest relevant network in Europe involving 500 higher education and research institutions and services for mobile researchers. 
IT Courses: The University organizes several courses on Information and Communication Technology on its premises to support refugee skills in new technologies (Microsoft Office, e-mail management, website creation) or has supported several others initiatives (see Table S1, Supplementary Materials) of other institutions that wished to offer these courses.

An important training program for teachers wishing to educate refugee children is offered free of charge by the University of the Aegean. The training program's duration is 300 hours (150 hours for each subject), and two main subjects are covered: (a) Language and Bilingualism in Intercultural Environments and (b) Digital Literacy in Intercultural Environments.

The UAeg is organizing a series of school education programs. Some of them also involve the participation of refugee children from the educational primary and secondary levels.

\subsubsection{Study of the Refugee Phenomenon}

One important University initiative is the Refugee and Migration Crisis Observatory. The Depositary for the Refugee and Migration Crisis Observatory in the Aegean is supported by the National Documentation Center, the University of the Aegean, and the Wenner-Gren Foundation for Anthropological Research. Its objectives are to collect, process, classify, digitize, and publicize various categories of evidence related to the refugee and migratory crisis in the Aegean. The Depository objective is to be a key source of reliable information and reporting to the research community in Greece and abroad, local communities as well as public administration and humanitarian authorities and the displaced people themselves.

The UAeg organizes a series of summer courses to study the refugee phenomenon such as one entitled "Cultures, migrations, borders", which examines migration processes and the "refugee crisis". In addition, significant conferences have been organized such as the "Lesbos Dialogues" (9-11 November 2017) on Mytilene (Lesbos) by the University of Agder, Norway and the Municipality of Lesvos, in cooperation with the UAeg (University of Agder 2019).

\subsubsection{Community Integration}

Recent research findings show that refugees in Greece experience psychological distress because of the loss of social networks and the high uncertainty in their life (Bjertrup et al. 2018). People in the camps face problems such as inhumane living conditions, lack of information, humiliation, and depersonalization (Eleftherakos et al. 2018). Inaction in camps during the long "frozen transit" causes discontent, disappointment, anger, indignation, and pessimism. The absence of interactions with the surrounding Greek social network has led to feelings of isolation and being unwelcome (Bjertrup et al. 2018). Necessary actions for the social integration of refugees are taken through volunteer and community engagement (Kourachanis 2018). On the other hand, small island societies that have to co-operate with thousands of refugees need support to be able to understand the new reality and minimize hostile opposition and racist and xenophobic reactions.

The UAeg has worked intensively to improve the local awareness toward refugee matters and enhance peaceful coexistence. Several initiatives are taking place such as exhibitions, social events, and common actions. Some examples are presented here. The "AEGEAN 50:50—Balanced Participation" Committee of the University of the Aegean, in collaboration with the United Nations High Commissioner for Refugees and the South Aegean Regional Directorate for Primary and Secondary Education, and in the context of actions undertaken to raise awareness of the gender dimension of the refugee phenomenon, organized an event entitled "Beyond the Borders: Intercultural Meetings of Women". Based on this event's framework, a cooperation agreement was signed between the School of Humanities of the University of the Aegean, the UN High Commissioner for Refugees, and the Regional Department of Higher Education in South Aegean.

On 6 June 2016, the University of the Aegean in Mytilene, Greece showed the "The Global Chess Board" to an entire audience. The chess board was made of recycled material—waste paper collected on the campus by the students and used refugee life jackets obtained from the Municipality of Lesvos 
(Figure S1, Supplementary Materials). The waste paper symbolized the movement to protect the environment and eliminate waste by recycling and the second material from the life jackets was used to strengthen the local community awareness related to the refugee problems. UAeg students organized the exhibition under the title "Human nature is like water; nothing stops it", inspired by the refugee crisis.

\subsubsection{Sustainable Refugee Camps}

The refugee camps were created in a hurry without any urban planning, in available open spaces. Hundreds of tents were set up as temporary accommodation. Gradually, they developed into crowded camps of inadequate infrastructure that serve thousands of people (Theofanidis and Fountouki 2019). The accumulation of garbage and plastic inside the camps, the overflow of the septic tanks, and the need for more sustainable energy are some of the major environmental issues inside the camps. The UAeg responded to the huge environmental problems of the camps by designing a new project related to the recycling of plastics. Linking the recycling value to economic, social, and environmental incentives in circular economy and sustainable development is the target of the overall project entitled "Trash to Treasure". The project was presented at Conseil Européen pour la Recherche Nucléaire (CERN) initiative "Globe of Science \& Innovation" as flagship, held on 8 October 2018. The Lesvos proposal suggests the solution of a pressing problem, such as that of waste accumulation in the refugee camps, with the development of the "Intelligent Recycle Bin" accompanied by the standard Digital Recycling Application. By focusing on circular economy, the project aims to encourage the active participation of refugees in improving living conditions in their centers of residence through awareness of the value of "waste" and, in general, the protection of the environment. Other strong points of the project include the parallel support of the refugee community, by exploiting and developing their skills, with their education and employment opportunities, as well as encouraging the exchange of knowledge and creative cooperation with the local community. A further aim is the generalization of application in places and conditions of collective action, such as schools.

\section{Discussion}

The current refugee crisis brought to the surface the memories of the Asia Minor Catastrophe (1922) and the compulsory population exchange between Greece and Turkey. After the Lausanne Convention (24 July 1923). About 1.5 million refugees arrived from Turkey in an almost bankrupt Greece, which had to provide food and accommodation to them as a matter of urgency. The major difference is that the Asia Minor Catastrophe created an ethnically and religiously homogenous country. In contrast, the number of refugees that remain during the recent migrant influx (from 2015 to today) in Greece is relatively small in relation to the numbers seen in the Asia Minor Catastrophe, but there are serious impacts related to linguistic, cultural, and religious differences.

The continuing Greek economic recession creates severe hazards in the social infrastructures with direct consequences on the educational sector. In many schools in deprived areas, charitable organizations hand out food or school material to the students. Within these schools, the attitude toward migrant children was xenophobic because the schools were already suffering from limited staff and infrastructure. In addition, migrant children do not get routine vaccination before attending school (Lazaratou et al. 2017) which created anxiety among Greek parents. However, attitudes soon improved and the REHS operation became normal.

The operation of the limited number of inter-cultural schools did not fulfill their educational goals, and the attendance of refugees and immigrant children in conventional schools proved to be more efficient. The educational outcomes of the inter-cultural schools are strongly questionable according to recent findings (Mitakidou et al. 2007), which showed lower progress among the international students in comparison with those that attend conventional schools. The inadequate level of Trainers' training and the fragmentary way in which curricula were developed resulted in the use of traditional educational methods instead of a holistic approach on various subjects, the untapped exploitation 
of the students' linguistic and cultural backgrounds, and the excessive effort in the teaching of the Greek language. Despite the small attendance and the high drop-out rate from the REHSs and their initial weaknesses in their organization, the REHSs proved to be an efficient educational preliminary structure to cover the prerequisites for children to enter the conventional schools.

In order to improve the integration of refugee children into the Greek educational system, the following suggestions can be made:

(a) support in learning Greek;

(b) the organization of intensive courses for those children who have been left out of school for a long time and have important educational gaps as well as for illiterate children;

(c) support of the refugee children after school hours;

(d) the organization of the mechanism and the procedures to certify secondary level knowledge (for those under 15 years of age) required for children who lack the necessary certificates;

(e) the formation of parallel classes for the children to continue to study their mother language. Finally, a better flow of information should be set between schools and parents to eliminate the phenomenon of dropping out or incomplete attendance.

Greek universities and especially the UAeg have responded in various ways to the migrant influx and have taken steps to reduce political, institutional, and societal constraints, which oppose refugee integration. In order to achieve the integration of the young scientists, researchers, and academics into Greek universities, the following suggestions can be made:

(a) the learning of Greek (one of the most serious limitations);

(b) the establishment of a preparatory year of courses for migrant students who interrupted their studies or have not yet entered university;

(c) the establishment of new rules to facilitate the easier enrollment into tertiary education;

(d) the introduction of low tuition fees or free of charge attendance;

(e) the creation of new funding schemes for refugee students, researchers, academics, and scientists and for the establishment of common educational programs between Greece and Syria (the origin countries of almost $50 \%$ of the children).

Foreign graduates face difficulties in returning home when the political conditions in their country remain negative or insecure. If the labor market of their home countries needs their scientific expertise and offers them a position in the country's leadership or social benefits, then their return can be taken as granted (International Affair Institute 2012). The refugee in-flows have initiated not only innovated curricula but also innovation services, technologies and methodologies that, with appropriate planning, could bring a multiplier effect in the university, the refugees, their home countries, and in Greek society. The modernization of camps is a necessary step closer to socio-economic integration, environmental sustainability, and consistency with local development plans (Jahre et al. 2018).

However, Greece is facing difficulties in managing the refugee influx and especially in the process of incorporating the refugees into its society, even though the number of non-European immigrants is still at a low level (5.7\%) in comparison to the total population. Greek academic institutes educate only $4 \%$ of non-Greek speaking foreign students, and the incorporation of migrants should increase this proportion and initiate new curricula and improvements that could increase their visibility and internationalization. Moreover, at the European level, specific policies should help in that direction such as:

(a) the dissemination of the existing research on the situation of refugees and migration to society and to policymakers;

(b) the creation of an international platform for exchange and collaboration, that would foster long-term synergies (Higher Education Institutes (HEIs), NGOs, regional authorities, private sector); 
(c) the continuous support of programs for HEIs and NGOs to share best practices and strengthen the voice of HEIs;

(d) the harmonization of migration policies inside the European Union to allow the better mobility of migrant students and researchers.

\section{Conclusions}

Greece is a country with low numbers of non-European Union (EU) origin immigrants (5.7\%), with the majority of the legally residing foreigners coming from Albania (69\%). Even though the internationalization rate of Greek universities is high ( $10 \%)$ with the majority of foreign students coming from Cyprus $(60 \%)$ and from the Middle East and Turkey $(20 \%)$, the attendance by non-Greek speaking students is limited to only $\sim 4 \%$.

The recent migrant influx has resulted in more than 58,000 refugees and asylum seekers, mainly from Syria, Afghanistan, and Iraq, remaining in Greece. The need for schooling of their children has grown very rapidly, as well as additional needs emerging for their integration into the labor market (Eggenhofer-Rehart et al. 2018) and the academic market and, generally, into Greek society. The new structures such as the REHSs serve as the preparatory work in order for the children to be fully integrated into conventional schools. Despite the main organizational and bureaucratic constraints, much progress has been made to convince children and their parents to attend school classes regularly, to improve their linguistic cognition, and to integrate. On the other hand, the academic sector has started new plans to face the refugee flow challenge and worked in several directions. Currently, the necessary reforms, actions, and plans are known and should be implemented in order to prepare the migrant group to adapt to Greece or to return to their home countries.

Supplementary Materials: The following are available online at http:/ / www.mdpi.com/2076-0760/8/3/72/s1, Figure S1: Initiatives of University of the Aegean (UAeg) related to the social integration of migrants, Table S1: Information Activities of University of the Aegean (UAeg) related to migrants support and education.

Author Contributions: O.T. designed the descriptive study, collected, analyzed the findings and wrote the article.

Funding: This research was funded by the SCIREA European Union HORIZON project "Science for Refugee Scientists in Aegean Archipelago" (Grant agreement Identity Document: 786332), http:/ / scirea.aegean.gr/index. php.

Acknowledgments: The author wishes to thank S. Scleparis for proofreading the article.

Conflicts of Interest: The authors declare no conflict of interest.

\section{References}

Afouxenidis, Alex, Michalis Petrou, George Kandylis, Angelo Tramountanis, and Dora Giannaki. 2017. Dealing with a Humanitarian Crisis: Refugees on the Eastern EU Border of the Island of Lesvos. Journal of Applied Security Research 12: 7-39. [CrossRef]

Bjertrup, Pia Juul, Malika Bouhenia, Philippe Mayaud, Clément Perrin, Jihane Ben Farhat, and Karl Blanchet. 2018. A Life in Waiting: Refugees' Mental Health and Narratives of Social Suffering after European Union Border Closures in March 2016. Social Science and Medicine 215: 53-60. [CrossRef] [PubMed]

Database. 2008. Quantitative and Statistical Data for Students and Foreign Students, 6th Intercultural \& All Day Elementary School of Eleftherio-Kordelio. Available online: http:/ / 6dim-diap-elefth.thess.sch.gr/ Greek/Diapolitismiki_Ekpaidefsi/StatistikaStoixeia/StatistikaStoixeiaPalAllMathhtwn.htm (accessed on 1 September 2018).

Eggenhofer-Rehart, Petra M., Markus Latzke, Katharina Pernkopf, Dominik Zellhofer, Wolfgang Mayrhofer, and Johannes Steyrer. 2018. Refugees' Career Capital Welcome? Afghan and Syrian Refugee Job Seekers in Austria. Journal of Vocational Behavior 105: 31-45. [CrossRef]

Eleftherakos, Christos, Wilma van den Boogaard, Declan Barry, Nathalie Severy, Ioanna Kotsioni, and Louise Roland-Gosselin. 2018. "I Prefer Dying Fast than Dying Slowly”, How Institutional Abuse Worsens the Mental Health of Stranded Syrian, Afghan and Congolese Migrants on Lesbos Island Following the Implementation of EU-Turkey Deal. Conflict and Health 12: 38. [CrossRef] [PubMed] 
ELSTAT. 2018. The Hellenic Statistical Authority (ELSTAT) through the Quarterly Publication Greece in Figures, April-June 2018. Edited by Division of Statistical Information and Publications of ELSTAT. Available online: http:/ / www.statistics.gr/documents/20181/1515741/GreeceInFigures_2018Q2_EN.pdf/e0ef5a1bdcd4-495a-bf4a-7c04d7c4eebf (accessed on 1 September 2018).

Konstantinou, Alexandros, Athanasia Georgopoulou, Aikaterini Drakopoulou, Vasilis Fragkos, and Kleio Nikolopoulou. 2018. Country Report: Greece. Edited by Greek Council for Refugees as part of the Asylum Information Database (AIDA). Available online: file:/ / C:/Users/user/Downloads/aida_gr_ 2017update.pdf (accessed on 25 February 2019).

IEF. 2007. Distribution of Foreigners and Repatriated Students in Public Schools at School Year 2006-07, Institute of Education of Foreigners and Intercultural Education. Available online: http: / / 6dim-diap-elefth.thess.sch.gr/Greek/Diapolitismiki_Ekpaidefsi/StatistikaStoixeia/PalAllMathhtes / 2006_07_katanomi_allodapon_pallinostounton.pdf (accessed on 1 September 2018).

International Affair Institute. 2012. Greece's National Report on the Study of the European Migration Network on the Migration to EU Students from Third Countries. Available online: https:/ / ec.europa.eu/home-affairs/sites/homeaffairs / files/what-we-do/networks/european_ migration_network/reports/docs/emn-studies/immigration-students/11b._greece_national_report_ immigration_of_international_students_final_nov2012_gr_version_en.pdf (accessed on 1 September 2018).

Jahre, Marianne, Joakim Kembro, Anicet Adjahossou, and Nezih Altay. 2018. Approaches to the Design of Refugee Camps. Journal of Humanitarian Logistics and Supply Chain Management 8: 323-45. [CrossRef]

Kapucu, Naim, and Sana Khosa. 2013. Disaster Resiliency and Culture of Preparedness for University and College Campuses. Administration and Society 45: 3-37. [CrossRef]

Kourachanis, Nikos. 2018. From Camps to Social Integration? Social Housing Interventions for Asylum Seekers in Greece. International Journal of Sociology and Social Policy. [CrossRef]

Lazaratou, Helen, Marina Economou, and Dimitris Dikeos. 2017. Greek Public's Ambivalence toward Refugee Children Education. International Journal of Social Psychiatry 63: 800. [CrossRef] [PubMed]

Mavrommatis, George. 2018. Grasping the Meaning of Integration in an Era of (Forced) Mobility: Ethnographic Insights from an Informal Refugee Camp. Mobilities 13: 861-75. [CrossRef]

Ministry of Education. 2017. The, Scientific Committee for Refugees, The Work of Refugee Education A. Project Evaluation Report on the Integration of Refugee Children in Education (March 2016-April 2017) B. Proposals for the Education of Children of Refugees in the School Year 2017-2. Available online: https://www.minedu.gov.gr/publications/docs2017/16_06_17_Epistimoniki_Epitropi_Prosfygon_ YPPETH_Apotimisi_Protaseis_2016_2017_Final.pdf (accessed on 1 September 2018).

Mitakidou, Christodoula, Danielidou Evgenia, and Tourtouras Christos. 2007. Intercultural Schools: Reality and Perspectives. In Primary Education and the Challenges of Our Time, Ioannina, 17-20/5/2007. Edited by Georgios Kapsalis and Apostolos Katsikis. Available online: http://ikee.lib.auth.gr/record/133041 (accessed on 1 September 2018).

OECD.Stat. 2019. Foreign/International Students Enrolled Data. Available online: https://stats.oecd.org/Index. aspx?DataSetCode=RFOREIGN (accessed on 1 September 2018).

Streitwieser, Bernhard, Lukas Brueck, Rachel Moody, and Margaret Taylor. 2017. The Potential and Reality of New Refugees Entering German Higher Education: The Case of Berlin Institutions. European Education 49: 231-52. [CrossRef]

SCIREA. 2018. The SCIREA Project Home Page. Available online: http:/ / scirea.aegean.gr/index.php (accessed on 1 September 2018).

CGL. 2018. The CGL of the Ministry of Education Home Page. Available online: http:/ /www.greek-language.gr/ certification/ (accessed on 1 September 2018).

Theofanidis, Dimitrios, and Antigoni Fountouki. 2019. Refugees and Migrants in Greece: An Ethnographic Reflective Case Study. Journal of Transcultural Nursing 30: 26-31. [CrossRef] [PubMed]

UNHCR. 2017. Greece Data Snapshot-25 July 2017: 1. Available online: https://data2.unhcr.org/en/documents / details/58585 (accessed on 1 September 2018).

UNHCR. 2018a. Inter-Agency Consultation Forum Meeting Minutes. Paper presented at General Secretariat for the Aegean and Island Policy, Mytilne, Lesvos, Greece, June 21.

UNHCR. 2018b. Greece Lesvos Weekly Snapshot, 25 June-1 July 2018. Available online: http:/ /www.statewatch. org/news/2018/jul/unhcr-lesvos-weekly-snapshot.pdf (accessed on 1 September 2018). 
UNHCR. 2018c. Information Report, Aegean Islands, 1-31 Mai 2018. Available online: https:/ / data2.unhcr.org/ en/documents / download/ 64326 (accessed on 1 September 2018).

University of Agder. 2019. Lesbos Dialogues. Available online: https://lesbosdialogues.uia.no/technology/ (accessed on 1 September 2018).

Visconti, Louisa, and Diane Gal. 2018. Regional Collaboration to Strengthen Education for Nationals \& Syrian Refugees in Arabic Speaking Host Countries. International Journal of Educational Development 61: 106-16.

Zsófia, Nagy. 2018. From Camps to Schools: The Participation of Refugee Children in Greek Public Education. Journal of Modern Greek Studies 36: 373-99. [CrossRef]

(C) 2019 by the author. Licensee MDPI, Basel, Switzerland. This article is an open access article distributed under the terms and conditions of the Creative Commons Attribution (CC BY) license (http://creativecommons.org/licenses/by/4.0/). 